\title{
ABALROAMENTO ÁÉREO
}

\author{
José Dalmo Fairbanks Belfort de Mattos \\ Professor da Faculdade de Direito da Universida- \\ de de São Paulo; Professor nas Faculdades Pau- \\ lista de Direito - Pontifícia Universidade Católi- \\ ca de São Paulo - e na de Campinas.
}

\section{INTRODUÇÃO}

\section{O ABALROAMENTO NAVAL ATRAVEZ DOS TEMPOS}

ABALROAÇÃO - define Silva Costa - é o choque entre dois navios ou embarcações, que navegam, ou estão em condições de navegar, dentro ou fóra dos portos.

Instituto conhecido desde os primórdios da civilização mediterrânea. Desde os tempos da protohistória, quando as naves cretenses possuiam quasi o monopólio do comércio no Mediterrâneo e no Egeu...

Choque náutico, que poderia sobrevir por motivo hostil, ou sem êle, - abrangia, a princípio, num só conceito, a colisão fortuita de duas triremes, imersas no nevoeiro, ou o assalto de piratas, ávidos de saque.

Esta fusão inicial de noções revela-se, até hoje, no exame léxico do termo.

ABORDAGE significa em francês, a um tempo, o abalroamento de navios mercantes, ou a operação bélica de abordagem, visando o apresamento ou captura de uma embarcação. 
Em inglês, TO BOARD quer dizer, simultaneamente, abalroar e abordar. E, no português arcaico, balroas eram os "arpeus com fateixas", que os piratas lançavam sôbre o navio cubiçado, no ato de assaltá-lo.

Eram os célebres "arpeus de abordagem", que, arrojados por mãos hábeis, engatavam-se no aparelho da presa, e a uniam fortemente aos barcos inimigos...

"Levar de balroada" queria dizer também, no seiscentismo, agredir de surpreza, acometer de súbito o adversário, levando-o de roldão...

O "Código de Hamurabi" (2.600 A.C.) parece conter o primeiro texto, regulando o resarcimento dos danos, provenientes das colisões marítimas ou fluviais.

"Si um barco a remos investe contra um barco a ve"la, e o põe a pique, deverá o patrão do barco que foi "posto a pique pedir justiça deante de Deus, e o pa"trão do barco a remos, que mete a fundo o barco a "vela, deverá indenizar o seu barco, e tudo quanto se "perdeu". (art. 240) - (1)

Tratava-se, provàvelmente, de culpa presumida. 0 batel a remos dependia, em sua derrota, diretamente da vontade humana, ao passo que o veleiro sofria o influxo das correntes aéreas. Era menos manejável, menos dócil ao leme. Daí presumir-se sua inocência, no choque verificado.

Não se conhecem textos romanos, àcerca do abalroamento. Mas a instituição deve haver existido, talvês no bojo de certos costumes vigentes, qual direito consuetudinário, entre os mercadores do mar.

Revela-se ela, pujante, na Idade Média. Tanto nos "Rôles d'Oléron", como nas "Leis de Wisby"; abriga-se no "Consolato del Mare", como nas "Tábuas de Amalfi".

Tese apresentada ao $3 .^{\circ}$ Congresso Brasileiro de Aeronáutica.

(1) ap. - João C. da Rocha Cabral, "Duas Lições sôbre Direito Navegacional". 
Figura, sob o nome de "abordage", na Ordenança de Luís XIV. Passa dalí para o Código Comercial francês. Atinge o brasileiro, em 1850, em seu art. 749. Constitui os arts. 664 a 675 do Código Comercial Português.

Como ato ilícito penal, o Código de 1890 consagra os arts. 145 e 146 aos abalroamentos, doloso e culposo.

Já a Consolidação das Leis Penais não o estuda, como figura criminal autônoma; o Projeto Alcântara Machado pune, no art. 236, os que causam "submersão ou naufrágio de embarcação", sem especificar a causa instrumental do delito.

E o Código Penal de 1940 prevê, no art. 261, o crime de "expôr a perigo embarcação... própria ou alheia", quer dêsse ato provenha ou não encalhe ou naufrágio.

A importância da matéria para o comércio marítimo apressou o trabalho de unificação legislativa.

Uma CONFERENNCIA MARÍTIMA INTERNACIONAL reuniu-se em Bruxelas, em 1910 daí se originando uma Convenção, promulgada entre nós pelo Decreto 10.773, de 18-1-1914. E revista, por duas vezes, em 1924 e 1926.

Os grandes princípios normativos são aceitos quasi universalmente. Surgem, porém, divergências quanto a minúcias e consequências secundárias.

Assim, o abalroamento pressupõe embarcações em movimento, ou com possibilidade de mover-se. Não existe,

"Quando o choque se dá entre navios e construções "hidráulicas, pontes, estabelecimentos balneários, cas"cos de navios submersos" (2).

Para Silva Costa, também não constituiria abalroação, no sentido jurídico do têrmo, chocar-se um vapor contra um pontão ou uma dragadora; o entrechoque verificado numa ponte de barcas, ou colidir uma embarcação com um navio-farol. Eis que tais veículos não estão em condições de navegar. (Vol. II. ${ }^{\circ}$, n. $\left.{ }^{0} 228\right)$.

(2) Silva Costa, vol. 2. ${ }^{\circ}$ n..$^{\circ} 228$; Weil, n. ${ }^{\circ} 339$; Pipia, n..$^{\circ} 237$; Brunetti, números 576 e 735; Ach. Bevilacqua - comentários ao art. 749. 
ÁSCOLI, ao contrário, fala de choques entre navios ancorados e outros em movimento, como se enquadrando também na noção de abalroamento.

Pouco importa que um dos navios colidentes seja uma belonave. 0 Estado será responsável pelos danos, segundo os têrmos da Lei comum. (Supremo Tribunal Federal, - Acórdão, proferido em grau de embargos, na apelação civel 8.031, in D. J. U., 19-4-50, pág. 1.210).

Pipia chega a afirmar que, em casos tais, pode o Estado extrangeiro ser demandado perante os tribunais do País, em cujas águas territoriais se der a colisão. Opinião exagerada por certo, eis que sòmente o beneplácito das autoridades representativas do Estado poderá levá-lo a responder, como Réu, perante Côrtes extrangeiras.

A responsabilidade civil, no abalroamento náutico nasce exclusivamente da culpa. ESTA NÃO SE PRESUME (Código Comercial Português, art. 669). Decorre sòmente de fatos claros e insusceptíveis de qualquer dúvida (Convenção de Bruxelas, art. $\left.6 .^{\circ}\right)$.

Tal culpa pode concretizar-se, no entanto, com ou sem falta do capitão; decorre de um êrro de manobra, imputável a êste, ou de um defeito na construção, ou no aparelhamento do barco, atribuível ao armador.

Os danos oriundos do abalroamento constituem, em geral, avaria simples. Passarão, no entanto, à categoria de avarias grossas, caso o abalroamento haja sido provocado, para evitar mal maior (Código argentino, art. 1.271).

Admite-se o sequestro do navio culpado, que venha abrigar-se em águas brasileiras, ainda que o evento se haja verificado fora das águas territoriais (SUPREMO TRIBUNAL FEDERAL, Acórdão proferido aos 22-2-1908 - in "Direito" 105/630).

Tal é, em resumo, o instituto, que a descoberta da navegação aérea transplantou para um meio novo. Instituto profundamente humano, procurando harmonizar as consequências da culpa, com a aleatória "fortuna do mar". 
II. ${ }^{0}$ )

\section{GÊEESE DO INSTITUTO DO ABALROAMENTO AÉREO}

O desenvolvimento da aero-navegação fez surgir a possibilidade de colisões de naves no ar.

Possibilidade meramente teórica, a princípio. Pois seria altamente improvável uma colisão entre dois ou três balöes, esparsos pelo mundo, a realizar pequenos vôos, ou ascenções circenses.

Verificou-se, desde cedo, a possibilidade de choques entre aerostatos e edifícios. Principalmente, antes de descobrir-se a dirigibilidade dos balões.

Assim, Zambecari despedaçou-se, em 1812, de encontro a uma árvore, perto de Bolonha. Mme. Blanchard morreu, aos 6-7-1819, ao bater com seu globo sôbre um telhado, em Paris.

Porém, colisões entre aeronaves, só muito mais tarde vieram a ocorrer. Conhecem-se alguns exemplos, durante as grandes ofensivas aéreas aliadas, em Junho de 1918.

Em tempo de paz, os choques tornaram-se frequentes, a partir de 1919:-

a) - nas proximidades dos aeroportos, em vista do número reduzido de pistas de aterrissagem, e falta absoluta de serviços técnicos na infra-estrutura (torres de comando, etc.) ;

b) - na travessia das fronteiras, dada a exiguidade dos "corredores de passagem", previstos pela Convenção de Paris.

Os juristas pensaram aplicar, desde logo, aos abalroamentos aéreos as normas correspondentes do direito marítimo.

A analogia impunha-se. Acaso não era ela uma das principais fontes creadoras do "Direito Aêreo"? Fonte, que deixava de ser mero processo lógico de aplicação de normas, para tornar-se na elaboradora de um Direito Novo?

$\mathrm{E}$ o choque de aeronaves, perdidas no nevoeiro, não lembraria a colisão das antigas triremes? 
A semelhança jurídica entre o mar e o ar facilitava a existência de institutos comuns, - a extensão das normas consuetudinárias.

A mesma oposição, entre o território aéreo e a atmosfera livre - um a cobrir a terra e o mar territorial, outra a pairar sôbre o mar alto, - "res nullius, communis usus"...

E não era só. $O$ abalroamento entre aeronaves fazia surgir os mesmos problemas, que nasciam, outrora, da colisão entre navios:-

a) - pretensões de passageiros e expedidores contra o transportador;

b) - pretensão dos lesados contra o proprietário, fretador ou afretador do veículo, causador do abalroamento;

c) - conflito de interêsses entre os exploradores dos dois veículos;

d) - ações regressivas dos diversos exploradores contra os demais co-obrigados.

Por outro lado, a velha excusa da fortuna do mar ressurgia, agora, como causa excludente de responsabilidade de pilotos e companhias. Tornara-se, no dizer dos italianos, a "fortuna dell'aria"... neblina, má visibilidade, tufões, temporais...

Explica-se, pois, que as novas instituições se hajam decalcado sôbre os institutos correspondentes do direito marítimo.

Em algumas legislações, tal estado de cousas perdura até hoje. Assim, dizem Roberto Sandiford e Luigi Papi Spanu, na Itália,

"il nuovo Codice della Navigazione ha stabilito di es"tendere all'urto aeronautico le corrispondenti nor"me dell'urto nautico" ("Istituzioni di diritto della navegazione", 2. ${ }^{a}$ edição, pág. 558).

Em outras, como no Brasil, a analogia não é confessada; o decalque resulta, entretanto, nítido, do paralelismo de configurações jurídicas:- a enorme semelhança entre o art. 749 do Código Comercial, e o 127 do Código do Ar... 
Terceiro grupo de legislações, como a Lei Federal sôbre a Navegação Aérea da Suissa, invoca, para os casos omissos, o "direito comum" (art. 79). Isto é, no caso helvético, - o Código Federal Suisso das Obrigações (3).

\section{ABALROAMENTO AÉREO - O QUE SEJA}

Não há, também, completa concordância legislativa, no configurar o abalroamento aeronáutico.

Para o Código de Navegação Italiano,

"per urto aeronautico può intendersi lo scontrarsi di "due o più aeromobili che si trovino in volo".

Considera-se em vôo a aeronave, desde o início das manobras para a décolage, até o término das de pouso. Inclui-se, mais, na categoria do abalroamento aéreo, ex-vi do art. 974, "o choque entre uma aeronave em vôo, e um navio em movimento".

Para a Itália, portanto, o movimento é da essência da colisão.

Tal é, também, o conceito do art. 127 do Código Brasileiro do Ar. Para a nossa legislação em vigor,

"abàlroamento aéreo é qualquer colisão entre duas ou "mais aeronaves em movimento".

$0 \S$ único reproduz, também, uma disposição italiana:-

"Os danos causados por aeronaves em movimento a "outra aeronave, também em movimento, e às pessoas "nela embarcadas, consideram-se prejuizo de abalroa"mento, mesmo que não resulte colisão".

Interpretando êste inciso, o Prof. WALDEMAR FERREIRA vai além. Para êle, "movimento", na técnica legal, é sòmente movimento aéreo.

"A colisão em terra, dentro de aeroporto, sem ser em "manobra de partida ou chegada, não se conceitua co"mo abalroamento aeronáutico, mas como simples "choque de veículos, a recair sob o domínio do direito “comum" (pág. 275). 
Essa interpretação, a nosso vêr, perfeitamente exata frente à lei italiana, difìcilmente poderia aplicar-se ao Código Brasileiro do Ar.

Com efeito, o texto vigorante entre nós reproduz literalmente o italiano (caput). Mas não insere a definição restritiva, constante da parte final do aludido texto.

Assim, não distinguindo o legislador pátrio entre o deslocamento no ar e em terra, não seria lícito ao intérprete restringir inda mais o texto legal.

O conceituar do art. 127, já assinalou outrora, HUGO SIMMAS, é estreito e pouco defensável.

A tradição náutica incluia, na figura do abalroamento, a colisão entre um navio em marcha, e outro, "apto a movimentar-se". Ou entre uma nave e um acessório náutico levado à bubuia, pelas vagas.

A lei brasileira (seguindo os ensinamentos de Ambrosini, Cortesani e Cogliolo) preferiu exigir que ambas as aeronaves estivessem a mover-se, deixando de parte uma forma de colisões relativamente frequente nos aeroportos de grande movimento.

Assim, face à lei vigente, se um aeroplano em vôo rasante, chocar-se com outro pousado em terra, não haverá abalroamento. $\mathrm{E}$ também não ocorrerá esta figura jurídica, no caso de um avião, casualmente movimentado em terra, colidir com outro, parado no campo.

Por outra parte, entre nós, abalroarem-se navio e avião não constitui, de jure, abalroamento algum. Não será abalroamento naval, - pois o Código Comercial sòmente conceitua como abalroação "ser um navio abalroado POR OUTRO" (art. 749,

(3) O segundo sistema parece-nos o preferível. Porque permite criar normas específicas de direito aéreo, para certas situações peculiares, seguindo, nas demais, o velho padrão das leis marítimas. Por outro lado, não se nos afigura aconselhável o método suisso. 0 tipo padronizado das obrigações difìcilmente se aplica ao transporte aéreo, em face de suas características diferenciais. 
início). Não constituirá colisão aérea, pois, para configurá-la, exige o Código Brasileiro do Ar, pelo menos "DUAS AERONAVES EM MOVIMENTO".

Em casos tais, o lesado poderá resarcir-se pelo direito comum, invocando o art. 159 do Código Civil...

Um acórdão do Tribunal Marítimo Administrativo

A solução supra não agrada, entretanto, a todos os interessados.

Assim, vem o Tribunal Marítimo (ex-Tribunal Marítimo Administrativo) buscando equiparar as colisões aéro-navais aos abalroamentos marítimos, nos limites de sua jurisdição.

Firmou êle essa tese, em Acórdão, prolatado aos 22 de Janeiro de 1941 (4).

Tratava-se de um hidroplano extrangeiro, que, ao pousar em águas brasileiras, chocara-se contra o mastro de embarcação brasileira, fundeada no porto.

A competência do órgão contencioso administrativo defluia do art. $14 \S 1 .^{\circ}$ de seu Regimento Interno. Cabia-lhe julgar:

"os acidentes... verificados com aeronaves" (os "quais "ficarão sujeitos à apreciação do Tribunal "Marítimo Administrativo, quando ocasionados du"rante a flutuação dos referidos meios de transporte, "ou quando em vôo, colidirem ou atentarem, de qual"quer maneira, contra embarcações".

Cabia-lhe, pois, à época, aplicar o direito ao caso emergente.

Mas, que direito? Não se aplicava o Código Brasileiro do Ar. Pois (diz o Acórdão) "se não se chocarem duas ou mais aeronaves, depreende-se que não haverá abalroamento aéreo". Invocar-se-á o Código Comercial? Sim, argumentam os julgadores.

(4) Reproduzido por WALDEMAR FERREIRA - "Instituições", vol. 3.`, n. ${ }^{\circ} 1.302$. 
Pois estipula a Convenção Internacional para a salvaguarda da vida humana no mar:-

"segundo as regras internacionais para evitar abal"roamentos, AS AERONAVES, quando pousadas no "mar ENTRAM NA DEFINIÇÃO DE NAVIOS A "VAPÔR".

Ora (argumenta o julgado) a Convenção de Londres foi promulgada no Brasil, pelo decreto $n .^{0}$ 1.094, de 15-9-36. Logo, aplicável, como parte integrante do nosso direito interno.

Consequência:

"Dar-se-á, cumpre admitir, um abalroamento maríti"mo, se a colisão verificar-se entre a aeronave (em"barcação do ar) e o navio (embarcação do mar), a "despeito de até agora o direito marítimo ter condi"cionado o abalroamento à colisão de embarcações en"tre si".

A conclusão ultrapassa, visìvelmente as premissas.

A Convenção de Londres equipara a aeronave flutuante ao vapôr para fins de salvamento. E para aplicar-lhe "as regras internacionais" preventivas do abalroamento.

Isto é o Código Internacional de Sinais, e o regimen de luzes, adotado e atualizado entre nós pelo Regulamento do Tráfego Aéreo (Decr. 8.352, de 9-12-41).

Seria absurdo extender-lhe o âmbito, para fins de dirimir controvérsias pecuniárias, e atribuir os onus de reparação civil.

Cumpre notar, ainda que, no caso vertente, estando o navio fundeado, é duvidoso que pudesse ser considerado "apto a movimentar-se" - condição sine qua non para a concretização legal do abalroamento.

\section{CLASSES DE ABALROAÇÃO}

O direito aéreo adota, via de regra, a concepção subjetiva da responsabilidade. 
Distinguem-se vulgarmente três tipos de abalroamento:o fortuito, o motivado por culpa unilateral, e o proveniente de culpa recíproca (Lei aeronáutica francesa, art. 39 ; italiana, art. 52 ; dinamarquesa, arts. 220/221).

E - corolário da doutrina adotada: - no primeiro caso, nada há a indenizar; no segundo, o explorador culpado arca com as despezas; no terceiro, são elas partilhadas entre os co-responsáveis.

Excluem a responsabilidade: o caso furtuito, e a fôrça maior.

Nesta, poderemos incluir a "fortuna do ar", múltipla e vária: - cerração, má visibilidade, teto baixo, nevascas, granizo, ventos intensos. A inobservância das normas legais de vôo caracteriza a culpa; o mau funcionamento dos aparelhos da infra-estrutura (radar, torre de comando, balisagem do campo, etc.), constituindo culpa de terceiros destroi ou atenua a responsabilidade do explorador.

Sistema análogo parece ter sido o adotado pelo nosso Código do Ar. Embora a redação se revele imperfeita.

0 art. 128 configura o abalroamento unilateralmente culposo.

"A indenização, devida por prejuizos causados em "caso de abalroamento entre aeronaves cabe ao explo"rador da aeronave QUE TIVER CULPA".

0 art. 130 declara que "a responsabilidade é proporcional à gravidade das faltas cometidas", "se a culpa fôr comum às aeronaves".

E o § único determina: -

“Se não puder ser estabelecida a proporção, divide-se

"a responsabilidade em partes iguais".

Cópia literal do ante-projeto internacional do CITEJA. 0 qual, por sua vês, reproduz e consolida uma "constante" de direito, - vinda, aliás, das velhas normas consuetudinárias. 


\section{CRITÉRIOS FIXADORES DE INDENIZAÇÃO}

Concordam as legislações nacionais em limitar o montante da responsabilidade, em caso de colisão aérea. É uma verdadeira "constante", - trazida do Direito Marítimo. E fruto das considerações populares sôbre o risco navegacional.

Divergem, entretanto, os critérios de fixação dos limites.

Para os italianos, o quantum é função do peso do aparelho culpado. Isto porque o peso é elemento preponderante no cálculo da força-viva, e esta, fator primordial dos danos. ( 0 outro elemento - a velocidade - constituiria fato de comprovação difícil, maximé se o abalroamento destruisse os aparelhos de bordo).

0 resarcimento é calculado na base de 300 liras por quilo. $\mathrm{E}$ o peso calcula-se, considerando-se o avião carregado com a carga máxima, prevista em seu certificado de navegabilidade.

A lei fixa um mínimo de 750.000 liras, e um limite máximo de 2.000.000, para as aeronaves comerciais. Tratando-se de avião de turismo, o mínimo é reduzido a 300.000 liras.

Em nossa legislação, ao contrário, prevalecem os critérios gerais de responsabilidade, fixados pelos arts. 91 e 102 do Código Brasileiro do Ar. Entretanto, haverá ou não rateio, e as avarias serão consideradas simples ou grossas, nos têrmos das leis marítimas, - equiparando formalmente a aeronave a navio.

Para fazer jús, no entanto, aos limites de responsabilidade supra referidos, torna-se necessária "a comunicação do abalroamento às autoridades do aeroporto mais próximo do acidente". Para as aeronaves brasileiras, esta obrigação perdura, mesmo que o evento haja ocorrido em mar alto.

São disposições expressas e imperativas do art. 131, e seu $\S$ único do Código do Ar.

Assim determinando, seguiu o Código do Ar a melhor doutrina, adotada na Itália por AMBROSINI e COGLIOLO, e amplamente desenvolvida por CESARE SAVOIA, em interessante obra, denominada "La Responsabilità Civile del vettore aéreo". 
No que tange a responsabilidade para com terceiros à superfície do solo, o Brasil é signatário da Convenção de Roma, de 1933. Bem como de sua alteração, firmada por Convênio de 7-10-52. Aplicar-se-ão aos abalroamentos, em que colidirem aviões brasileiros e extrangeiros, 0 art. $6 .^{\circ}$ da Convenção primitiva, reproduzido, com alterações na atual, sob n. ${ }^{0} 5$.

\section{QUAL O RESPONSÁVEL PELA INDENIZAÇÃO}

O Código Brasileiro do Ar usa da expressão "EXPLORADOR". Conceito amplo, que abrange quem esteja na posse da aeronave, e a utilize com fito de lucro. 0 explorador pode ser, portanto, o proprietário, o compromissário comprador, o usuário, ou o simples locatário do aparelho.

Tanto pode ser uma pessôa física, como uma Cia.

Caso, porém, a culpa incumba à administração dos aeroportos, será evidentemente responsável o Poder Público que o administrar.

Interessante reproduzir, a êste respeito, as $R E S O L U C ̧ \tilde{E} E S$ 16 e 17, aprovadas pelo Conselho da Interamerican Bar Association, em Março de 1954, por ocasião da $3 .^{a}$ Conferência Interamericana de Advogados.

Resoluções estas, baseadas na tese "Responsabilidade das Cias. de Aviação em caso de acidente, nas visinhanças dos aeroportos, por razões de insuficiência do aparelhamento técnico", de autoria do Prof. Dr. J. R. BELFORT DE MATTOS Filho:-

\section{RESOLUÇÃO 16 :-}

"Declara que as Cias. de navegação aérea são respon"sáveis pela morte de pessoas e destruição de edifí"cios, causados na visinhança dos aeroportos; as inde"nizações resultantes devem ter o seu limite acresci"do, quando exista culpa da administração do aero“porto, QUE SERÁ RESPONSÁVEL NESSA HIPó"TESE, cabendo a Cia. ação regressiva contra a ad"ministração". 
RESOLUÇÃO 17:-

"Em caso de prejuizos a terceiros, em terra, causa"dos pelo fato de serem insuficientes os aeroportos, "o limite de indenização deve ser aumentado; nos ca"sos em que a administração do aeroporto fôr respon"sável, à Cia. de aviação pode processar a administra"ção".

Caso estas sủgestões doutrinárias fossem adotadas no futuro, de lege ferenda, aplicar-se-iam, também, aos abalroamentos aéreos. Tanto mais que as visinhanças dos aeroportos constituem terreno de predileção para esta classe de acidentes.

Sua introdução, em nosso direito, daria aos "exploradores" ação regressiva contra a administração aeroportuária. E derrogaria, parcialmente, os limites estabelecidos pelo Código Brasileiro do Ar.

\section{II. ${ }^{a}$ PARTE}

\section{O ABALROAMENTO AÉREO E AS CONVENÇÕES INTERNACIONAIS}

É voz corrente entre autores nacionais e extrangeiros, que não existe Convenção alguma, competente para regular o abalroamento aeronáutico.

"L'abordage aérien", dizem, por exemplo, OTTO "RIESE e JEAN LACOUR, “n'a encore fait l'objet "d'aucune convention internationale" (Précis de droit "aérien, pg. 305)" Il n'existe encore aucun texte, qui, "dans le droit international, réglemente les rapports "des aéronefs entrés en collision, pour les dommages "qu'ils se causent respectivement.,

declara MAURICE LEMOINE, em seu magnífico “Traité de Droit Aérien", n. ${ }^{\circ}$ 969, pág. 649.

"Não existe, para o transporte internacional, nenhu"ma convenção sôbre o assunto",

ensina o Prof. Dr. SAMPAIO DE LACERDA, ("Curso de Direito Comercial Marítimo e Aeronáutico”, pág. 458). 
Realmente, não se nos depara um tratado de âmbito universal regulamentador da matéria em foco. Falta ao abalroamento aéreo um dêsses "law making treaties" - criadores de normas válidas erga omnes. Ou um dêsses costumes internacionais, de cunho geral, e tendentes à universalização.

A Convenção de Paris limitava-se, com efeito, a inserir, no anexo "D", certos preceitos técnicos, visando evitar futuras colisões entre aeronaves em vôo. Normas preventivas, acauteladoras da segurança na navegação. E não ditames aplicáveis à colisões, já verificadas. Regulava-se o sobrevôo das regiões próximas a aeroportos; assegurava-se uma certa ordem, nos pousos; gizavam-se regras de precedência na aterrissagem.

Nada havia, entretanto, quanto à responsabilidade civil de pilotos ou de transportadores, de proprietários ou locatários de aeronaves.

O mesmo silêncio nota-se na "Convenção Ibéro-Americana de Aviação Civil" (1926), ou no Convênio Pan-Americano de Havana, quanto à Navegação Aérea Comercial neste Hemisfério (1928).

Não encontramos, também, a mais leve referência ao abalroamento aéreo, quer nos tratados aeronáuticos, firmados pelo Itamaratí, quer nos Acôrdos entre Países Estrangeiros.

Nada se estipula a respeito, quer no Acôrdo Provisório entre a Suissa e o Reino da Hungria, negociado em Berna, aos 18-6-35; nem no "Arrangement" de Dublin", entre o Eire e os Estados Unidos (1937). Nada existe, ainda, no Tratado chileno-argentino, de 8-5-1942, ou no Acôrdo celebrado entre a $A r$ gentina e o Reino Unido.

Igual mutismo nota-se nas CONVENÇôES DE CHICAGO (tanto no Acôrdo Provisório, como no Definitivo), e na série de Tratados Internacionais, que dêles defluiram.

Explica-se tal modo de proceder. É que tais Convenções atinham-sé quasi exclusivamente ao Direito Público Aéreo, deixando para outros órgãos a elaboração de textos, pertinentes à exploração civil ou comercial da aeronavegação. 
Tal excusa não é, porém, invocável, para explicar a ausência de qualquer preceito normativo quanto às colisões aeronáuticas, na CONVENÇÃO DE VARSóVIA, quanto à responsabilidade do transportador (1928).

Nem explica a displicência da primitiva CONVENÇÃO DE ROMA, limitando-se a estabelecer, no art. $6 .^{\circ}$, a responsabilidade solidária dos aviões que se hajam chocado, no resarcimento dos prejuizos causados a terceiros, na superfície.

Atinha-se, com efeito, a Convenção de 1933 a acentuar a solidariedade passiva das aeronaves, face a prejudicados no solo. $\mathrm{E}$ acentuava, implicitamente, ser esta responsabilidade $o b$ jetiva, provinda exclusivamente do risco. E independente $d a$ noção de culpa. (5)

Outra lacuna foi preenchida pela "Convenção internacional para a salvaguarda da vida humana no mar", assinada em Londres, a 31-5-1929.

Equiparava ela as aeronaves a navios a vapôr, "segundo as regras internacionais para evitar o abalroamento", quando estivessem pousadas no mar.

Muitos problemas quedavam, porém, sem solução.

Haveria direito regressivo do transportador, proprietário da aeronave inocente, contra o "explorador" do veículo culpado, causador da colisão? Se lhe cabia, como e onde exercê-lo, mediante que leis, perante que tribunais?

Existiria ou não, no que tange a abalroamento aéreo, essa "competência concurrente", de jurisdições, que a C.P.J.I. afirmou, quanto a colisões em alto mar? ("Caso Lotus").

Haveria limite quantitativo nessa responsabilidade? ou vigorariam, apenas, as normas de direito marítimo, como queriam Riese e Lacour?

Perguntas que se tornavam dia a dia mais prementes. E que aspiravam a uma pronta solução, a bem do transporte aéreo internacional.

(5) Princípio reproduzido no art. 5..$^{\circ}$ da atual Convenção de Roma, revista em 52. 


\section{UMA SOLUÇÃO CONTINENTAL:- O CÓDICO}

\section{BUSTAMANTE}

Se não há, porém, uma regulamentação universal, quanto aos abalroamento aéreo e suas consequências pecuniárias, existe, desde 1928 uma codificação continental.

Nesse ano, - quando as linhas aeronáuticas internacionais eram ainda incipientes na América, - a $6 .^{a}$ Conferência Pan-Americana aprovou o "CóDIGO BUSTAMANTE". Hoje ratificado e promulgado por quatorze Estados dêste Hemisfério (Bolívia, Brasil, Cuba, Costa Rica, Chile, Equador, Guatemala, Haití, Honduras, Nicarágua, Panamá, República Dominicana, Salvador e Venezuela).

Realizam-se gestões visando a adesão da Espanha e de Portugal, o que tiraria à Convenção seu caráter regional, - dando. -lhe acesso aos Países Europeus.

Trata-se de um Código de Direito Internacional Privado, sómente aplicável entre os Estados contratantes ou aderentes (art. 2..$^{\circ}$ (6).

Abrange no Livro II. ${ }^{\circ}$ o comércio internacional. Comércio, do qual é espécie o transporte aéreo, estabelecido entre dois ou mais Estados.

Onde há veículos em movimento, existem riscos. $\mathrm{E}$ um dêles, - cada vês mais frequente, é o da colisão. Daí a necessidade de regular-lhe jurìdicamente os efeitos.

Sentiu-o o Código Bustamante.

0 abalroamento encontra-se incluido no Livro II. $^{0}$, título $3 .^{\circ}$, capítulo $2 .^{\circ}$ (arts. 289 a 294$)$.

Estranha ubicação! Figura, assim, sob a rubrica "Dos contratos especiais de comércio marítimo e aéreo", quando é, indiscutivelmente, um ato imprevisto, que gera, em alguns casos, responsabilidade extra-contratual.

(6) Vide "L'expérience du Code Bustamante, et celle des Traités de Montevideo en Amérique Latine", do autor desta tese. 
Falta, aliás, à Convenção de Havana, um princípio único, que imbua e oriente as normas aplicáveis.

O abalroamento fortuito, em águas territoriais, ou no espaço aéreo nacional, submete-se à lei do pavilhão, "se êste fôr comum", diz o art. 289. Caso contrário, aplicar-se-á a "lex loci", ex-vi do art. 290.

Essa mesma lei local, será a aplicável

"a todo o abalroamento culposo, em águas territoriais, "ou no espaço aéreo nacional", em virtude de expressa disposição do artigo seguinte.

Se o abalroamento se verificar em alto mar, ou no "livre espaço", será competente a lei do pavilhão, — na hipótese de ser êle comum a navios ou aeronaves em colisão.

Se as nacionalidades dos veículos forem diversas, e o abalroamento culposo, aplicar-se-á o direito nacional "do navio ou aeronave abalroada".

Mas,

"nos casos de abalroamento fortuito, no alto mar, ou "no espaço aéreo livre, entre navios ou aeronaves de "diferentes pavilhões, cada um suportará a metade da "soma total do dano, dividida segundo a lei de um dê"les, e a metade restante segundo a lei do outro". (art. 294)

O abalroamento constituirá avaria simples ou grossa? Caberá resposta à lei do pavilhão, nos têrmos do art. 288. E será essa mesma lei que determinará

"a proporção em que deve contribuir para suportar o "navio e a carga" (idem, ibidem).

A área de aplicação do Código Bustamante cobre atualmente cêrca de 13.000 .000 de quilômetros quadrados. Não conhecemos, entretanto qualquer Acórdão, nacional ou extrangeiro, que o haja invocado, no que respeita o abalroamento aeronáutico. 


\section{TENTATIVAS DE AMBITO UNIVERSAL}

Enquanto a $6 .^{\text {a }}$ Conferência Pan-Americana assim buscava resolver os conflitos de leis, nascidos da aeronavegação, diversas entidades buscavam, na Europa, uma solução universal.

a) - PROJETO DO C. J.I.A.

Coube a primazia ao Comité Juridique International de l'Aviation, - orgão doutrinário, cujo "CODE INTERNATIONAL DE L'AIR" vem sendo elaborado em sucessivos Congressos (7).

O abalroamento aéreo é contemplado em quatro artigos, no que respeita ao problema jurisdicional.

0 art. 26 estabelece aplicar-se à reparação, como princípio geral, a lei do Estado sobrevoado,

"sauf si les aéronefs sont de la même nationalité, au"quel cas la réparation des dommages est régie par "la loi du pavillon".

A ação de indenização poderá intentar-se, quer perante o tribunal do domicílio do Réu, quer perante o fôro "de l'immatriculation de l'aéronef", diz o art. 27.

A lei do pavilhão será a competente para estabelecer a reparação dos prejuizos causados a pessoas e bens, que se encontrem a bordo, caso os avióes colidentes possuam a mesma nacionalidade. Caberá, porém, ao direito do Estado sobrevoado estatuir sôbre a reparação devida, por prejuizos causados a seus nacionais.

Finalmente, o art. 28 prevê abalroamentos ocorridos sôbre alto mar, ou ao sobrevoar territórios de ninguém. Neste caso, "la réparation des dommages causés par un aéronef “à un autre aéronef, à des personnes ou à des biens... "est soumis à la loi du Tribunal, saisi par la partie "la plus diligente dans les limites de l'article précé"dent.

(7) Paris (1910); Genebra (1912); Francfort-sobre-o-Meno (1913); Mônaco (1921); Praga (1922); Roma (1924); Lyon (1925); Madrí (1928); e Budapest (1930). 
“Toutefois, si les aéronefs ont la même nationalité, "la réparation des dommages est régie par la loi du "pavillion".

Em resumo: - a soberania do Estado prevalece, como norma principal de competência; a lei nacional da aeronave fará, porém, sentir seu influxo, caso seja comum aos aparelhos, envolvidos no abalroamento, ou quando o sinistro ocorrer em áreas, que escapem à soberania estatal.

Esse critério mereceu o apláuso de vários tratadistas. Bosco e Makarov, entre outros. Representam a aplicação total das normas náuticas às colisões aéreas.

Duas objeções podem, porém, levantar-se aos textos do C. J. I. A.: -

1. ${ }^{\text {a) }}$ - Tendem a desaparecer, neste momento, as "terras de ninguém". 0 Continente Antártico encontra-se partilhado. Ao Norte, as soberanias do Canadá e da U.R.S.S. extendem-se sôbre os ice-fields do Mar Polar. A Base de Thule, no extremo septentrional da Groelândia, estabelecida pelos Estados Unidos, com autorização da Dinamarca, é uma sentinela do Mundo Ocidental (8).

$\left.2 .^{a}\right)$ - Não parece conveniente aplicar-se a lei nacional das aeronaves, no caso de incidente haver ocorrido no território (terrestre, marítimo ou aéreo) de outro Estado.

Combatendo êste inciso do projeto, Mario Scerni aventa uma situação tríplice: -

a) - se o abalroamento advem sôbre alto mar, aplicar-se-iam as leis náuticas, reguladoras da jurisdição (competências cumulativas, prevenção, etc.) ;

b) - se ocorrer sôbre o território de um Estado, seria competente a lei local; e,

(8) Vide - José Dalmo Fairbanks Belfort de Mattos - "Direito Público Aéreo"; pág. 98. 
c) - "se l'urto avvienne mentre gli aeromobili sono anco"ra in contatto con il terreno (o con le acque territo"riali di un Stato)... mi pare fuora di dubbio che le "conseguenze dell'urto debbiano essere rette della "legge locale" (pág. 365).

b) - PROJETO DO C.I.T.E.J.A.

O "Comité International Téchnique des Experts Juridique Aériens” (C.I.T.E.J.A.) elaborou, entre as duas guerras, um ante-projeto de convênio internacional sôbre a questão do abalroamento aéreo.

Definia-o como sendo

"toute collision survenant pour une cause quelconque, "entre deux ou plusieurs aéronefs en mouvement".

Excluia, pois, choques entre aeronaves e navios; entre aparelhos em vôo rasante e instalações da infra-estructura, entre hidroplanos e aparelhamentos portuários.

Escapariam, aliás, ao âmbito do Acôrdo os choques havidos entre uma aeronave em vôo e outra em pouso, - fenômeno possível num aeroporto ou em plataforma de porta-aviões.

Distinguia três espécies de abalroamentos:-

a) - os causados pela culpa universal de uma das aeronaves;

b) - os motivados pela culpa comum;

c) - os derivantes de caso fortuito, ou decorrentes de fôrça maior.

$\mathrm{Na}$ primeira hipótese, o resarcimento incumbiria, por inteiro, à aeronave culpada. No segundo, partilhar-se-ia proporcionalmente à gravidade dos êrros cometidos. Na última, enfim, não haveria indenização,

"nem quanto às aeronaves, nem quanto às pessoas ou

"bagagens aéro-transportadas".

Triunfo, pois, integral, da responsabilidade subjetiva, causa e medida da obrigação de indenizar. Frente, porém, a 
terceiros, situados à superfície, perdurava o critério da responsabilidade objetiva.

"Et, à cet égard, la Convention sur l'abordage aérien "sera complémentaire de la Convention de Roma", assinalava COQUOZ ("Le Droit Privé International Aérien", - 1938 - pág. 273).

Diversos artigos traçavam os limites máximos às indenizações.

A responsabilidade do transportador para com passageiros e cargas, existentes a seu bordo, está limitada pela Convenção de Varsóvia.

Para os prejuizos, causados ao outro avião, seus passageiros e cargas, o ante-projeto estabelecia um valôr proporcional ao peso do aparelho culpado. Ou seja 250 frs. - Poincaré por quilo, - flutuando entre 600.000 e 2.000 .000 de frs.

Dêstes, um terço reverteria para reparação de prequizos causado ao avião inocente, e aos bens por êle transportados. Os dois terços restantes visariam cobrir os prejuizos corporais, num máximo de 125.000 frs. por pessoa. Admitia-se, no entanto, revertessem em pról dos acidentados as sobras, decorrentes de outras parcelas da reparação.

Fatores vários dificultaram a aprovação internacional dêsse ante-projeto. De um lado, a disparidade de critérios norteadores do dever de resarcir; de outro, a diversidade das legislações nacionais, que seriam por vezes, profundamente alteradas, se o Govêrno atingisse a ratificação.

Deveria o ante-projeto ter sido discutido na reunião de Bruxelas (1938). Porém, "por proposta da delegação americana foi adiada... por considerarem a matéria não suficientemente amadurecida".

Veio, enfim, a Segunda Grande Guerra. Sobreveio a criação da I. C. A. O. o de sua Comissão Jurídica, que afirma conter implìcitamente em seu bojo, a dissolução do C.I.T.E.J.A. (Mórmente após a Conferência de Washington, em 1947). 


\section{c) - DEBATES NA I. C. A. 0.}

Como quer que seja, avocou a I.C.A.O. a discussão do ante-projeto. Debateu-o em Genebra (Maio de 1948), e enviou um questionário aos Estados Membros, solicitando-lhes resposta sôbre diversos aspectos pendentes.

0 assunto foi incluido sucessivamente na ordem do dia da $5 .^{\mathrm{a}}$, da $6 .^{\mathrm{a}}$ e da $7 .^{\mathrm{a}}$ sessões do Comité Jurídico da Organização Internacional de Aviação Civil.

Mas, quer em Taormina, quer em Montreal, quer no México, não houve tempo para discutí-lo.

Há, evidentemente, um certo receio de votar a questão, que perdura em aberto, embora o desenvolvimento crescente da aeronavegação, e a velocidade cada vez maior das aeronaves venham multiplicando os casos de abalroamento, nos aeroportos, e em suas imediações.

A carência de normas internacionais, universalmente admitidas, foi constatada entre nós, pela Procuradoria Geral da República, em parecer emitido no Recurso Extraordinário ... 16.000 (in "Revista Brasileira de Direito Aeronáutico", vol. II. ${ }^{\circ}$, págs. 184 e segts.) e tácitamente reconhecida pelo Egr. S. T. F. no Acórdão que então prolatou.

Tal lacuna deve ser preenchida com a possível brevidade, a bem da segurança do transporte aéreo.

\section{COTEJO DOS TEXTOS}

Como se vê, o Código Bustamante e o Projeto de "Código Internacional do Ar" diferem profundamente do ante-projeto, ora em estudo na I. C. A. 0.

Este será (se aprovado) uma fonte creadora de normas, aplicáveis diretamente aos casos emergentes. Criará, assim, direitos e obrigações novas, derrogatórias do direito interno dos Estados, que o adotarem.

O Código Bustamante, e o Projeto do C.J.I.A., ao contrário, apenas traçam princípios dirimidores de conflitos de leis 
no espaço. Optam ora pela lex loci, ora pela lei do pavilhão ou melhor, do País de matrícula da aeronave. Ou pela do Estado sobrevoado.

Não criam direito novo. Escolhem entre os existentes, invocando um dêles para julgar a controvérsia. Caso típico de "reenvio", na técnica internacional.

O Código Bustamante apresenta algumas nugas: - não define qualquer conceito. Não diz o que seja "território do Estado", o que constitua o "espaço aéreo livre".

Parece, aliás, que seu autor partilhava a doutrina das zonas de Fauchille, admitindo a soberania do Estado até uma certa altura. Altura que o Código não delimita.

Daí uma certa imprecisão nos textos, que criaria sérios problemas para sua aplicação jurisprudencial.

0 ante-projeto do C.I.T.E.J.A. parece-nos, pois, aquele que melhor poderia solver as múltiplas dificuldades jurídicas, decorrentes de abalroamentos, ocorridos em vôos internacionais.

Preferível, por ser mais uniforme em seus critérios sistemáticos. Preferível, por ser auto-aplicável. Preferível, enfim, por criar normas, válidas para todos os signatários e aderentes. $\mathrm{E}$ contribuir, assim, e poderosamente, para a unificação internacional do Direito Aéreo.

\section{CONCLUSÕES}

Do exposto se conclui : -

A) - Quanto ao Direito constituido: -

I. $\left.^{\circ}\right)$ - Que a responsabilidade civil, decorrente de abalroamentos, marítimos ou aéreos, baseia-se, desde os primórdios, na doutrina subjetiva (do dolo e da culpa) ;

II. $\left.^{\circ}\right)$ - Que o instituto do abalroamento procura harmonizar, assim, a segurança do transporte com os áleas, decorrentes da "fortuna do mar" e "do ar" (caso fortuito e força maior) ;

III. ${ }^{\circ}$ - Q Que a responsabilidade objetiva, decorrente do 
risco pode ser invocada, contra os aparelhos envolvidos num abalroamento aéreo, apenas pelos terceiros, situados à superficie, e prejudicados pelas consequências da colisão;

IV. $\left.{ }^{\circ}\right)$ - Mas que, mesmo em tal caso, cabe ação regressiva do explorador inocente contra o culpado, para resarcir-se da indenização desembolsada.

\section{B) - QUANTO AO DIREITO A CONSTITUIR : -}

I. $^{\circ}$ ) - Urge a aprovação de um Convênio Internacional, que uniformize, em âmbito universal, as consequências jurídicas do abalroamento;

II. $\left.{ }^{\circ}\right)$ - Será conveniente introduzir, tanto em direito interno, como no internacional, normas que estendam o instituto do abalroamento às colisões verificadas entre navios e aeronaves, em movimento, ou aptos para movimentar-se;

III. $\left.{ }^{\circ}\right)$ - Convém estabelecer expressamente a responsabilidade dos Estados, ou das entidades administradoras de aeroportos, pelos abalroamentos que se verifiquem no campo, ou suas circunvizinhanças, por motivo de falta ou mau funcionamento do aparelhamento técnico da infra-estructura;

IV. $\left.{ }^{\circ}\right)$ - Em tais caso, em direito interno, poderá ser a responsabilidade agravada, ultrapassando-se os limites óra estabelecidos pelo Código Brasileiro do Ar.

\section{BIBLIOGRAFIA}

Bevilacqua (Achilles) - Código Comercial Anotado. Rio, s/d.

Código Bustamante.

Código Comercial Brasileiro.

Coquoz (Raphael) - Le droit privé international aérien. Paris, 1938.

Ferreira (Waldemar) - Instituições de direito comercial (3.0 vol.) São Paulo, 1949.

Riese (Otto) e Lacour (J. T.) - Précis de droit aérien. - Lausanne, 1951. Sampaio de Lacerda - Curso de direito comercial marítimo e aeronáutico. Rio, 1949. 